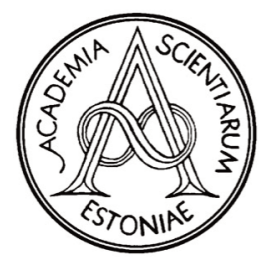

Proceedings of the Estonian Academy of Sciences, $2021,70,3,297-306$

https://doi.org/10.3176/proc.2021.3.08

CHEMISTRY

Available online at www.eap.ee/proceedings

\title{
Multivariate statistical analysis of heavy metals and physico-chemical parameters in the groundwater of Karak District, Khyber Pakhtunkhwa, Pakistan
}

\author{
Asif Khan ${ }^{\mathrm{a}}$, Muhammad Naeem ${ }^{\mathrm{a} *}$, Ivar Zekker ${ }^{\mathrm{b} *}$, Muhammad Balal Arian ${ }^{\mathrm{c}}$, Greg Michalskid, \\ Syed Zeeshan ${ }^{\mathrm{a}}$, Hameed ul Haq ${ }^{\mathrm{a}}$, Muhammad Ikramª, Abbas Khan ${ }^{\mathrm{a}}$, Fazle Subhan ${ }^{\mathrm{a}}$, Yahya Janie, \\ Zane Vincevica-Gaile ${ }^{\mathrm{f}}$, Muhammad Zahoor ${ }^{\mathrm{g}}$, Indrees Khan ${ }^{\mathrm{h}}$ and Muhammad Ishaq Ali Shah ${ }^{\mathrm{a}}$ \\ ${ }^{\text {a }}$ Department of Chemistry, AWKUM, Khyber Pakhtunkhwa, 23200 Pakistan \\ ${ }^{\mathrm{b}}$ Institute of Chemistry, University of Tartu, Ravila14a, 50411 Tartu, Estonia \\ ${ }^{\mathrm{c}}$ Department of Chemistry, University of Karachi, Sindh, 75270 Pakistan \\ ${ }^{\mathrm{d}}$ Department of Chemistry, Purdue University, West Lafayette, IN 47907, USA \\ ${ }^{\mathrm{e}}$ Department of Urban Studies, Unit of Built Environment and Environmental Science, Malmö University, 21119 Malmö, Sweden \\ ${ }_{\mathrm{f}}^{\mathrm{f}}$ Department of Environmental Science, University of Latvia, LV-1004 Riga, Latvia \\ ${ }^{g}$ Department of Biochemistry, University of Malakand, Chakdara, 18800 Pakistan \\ ${ }^{\mathrm{h}}$ Department of Chemistry, Bacha Khan University, Khyber Pakhtunkhwa, 24420 Pakistan
}

Received 4 June 2021, accepted 25 June 2021, available online 18 August 2021

(C) 2021 Authors. This is an Open Access article distributed under the terms and conditions of the Creative Commons AttributionNonCommercial 4.0 International License (http://creativecommons.org/licenses/by-nc/4.0/).

\begin{abstract}
Groundwater heavy metal pollution is a major concern all around the world. For the assessment of heavy metals and physico-chemical characteristics, groundwater samples were collected from different locations of the Karak District, Pakistan. With the help of the global information system device (GIS), groundwater samples were collected and studied from 47 locations. The present study focused on the water table (WT), water source depth (WSD), pH, electrical conductivity (EC), dissolved oxygen (DO), total dissolved solids (TDS), lead ( $\mathrm{Pb}(\mathrm{II})$ ), silver $(\mathrm{Ag}(\mathrm{I}))$, iron (Fe(II)) and chromium $(\mathrm{Cr}(\mathrm{VI}))$ parameters. Heavy metals were analyzed by the Atomic Absorption Spectrophotometer (AAS). The Pearson's matrix of correlation showed relationships between several parameters, such as the EC and the TDS which had close interactions between all the three different groundwater samples (collected by hand pump (HP), bore holes (BH) and tube wells (TW)). The strong correlation was detected in all the sources of water between the TDS and the EC, the regression coefficient $(r)$ of which was 1 . In the hierarchical clustering (by dendrograms) the HP samples show two clusters: Cluster 1 contains seven parameters and Cluster 2 has four parameters. The BH samples have two clusters: Cluster 1 contains three parameters and Cluster 2 has eight parameters. The TW dendrogram also shows two clusters: Cluster 1 contains six parameters while Cluster 2 has five parameters.
\end{abstract}

Key words: groundwater, clusters analysis, heavy metals, correlations.

\section{INTRODUCTION}

Groundwater is the most diverse and significant global water reservoir, which contributes approximately 34 percent of the overall yearly water supply [1] that promotes public health, monetary incentives and natural diversity; and the accessibility is restricted in many cases. Although groundwater exists within complicated subsurface structures, it is not immediately visible on the surface of the Earth. It is also a variable source, which is complicated to quantify in both space and time. Thus, statistical evaluation, effective management and usage of groundwater are also

\footnotetext{
*Corresponding authors, naeem@awkum.edu.pk, ivar.zekker@ut.ee
} 
important $[2,3]$. Typically, an interpretation of the effects of water quality has been performed on a single criterion, which prevents performing correlation on complexities and restricts simplicity estimations. On the other hand, the usage of a multivariate analysis jointly applying water quality parameters generates a detailed representation of the groundwater quality of a region based on certain interrelationships or correlations [4].

Contamination of groundwater involves point pollutants, residues and pollutants' discharges through factories, including furnaces and extraction, as well as nonpoint factors, including dissolved compounds (natural and artificial), the use of fertilizers and pesticides detected in the discharge of agricultural and urban sewage water and many more pollution sources [5]. Toxic and harmful heavy metals are used in the production of goods in several industries, such as textile and color/dye industries, paper production, food production industries, distilleries, refineries, chemicals factories, seafood production systems, pesticide industries and in the cement production. Pollutants are particularly present in small production plants in Bangladesh, where the pollutants are discharged completely untreated or partially treated into the river [5].

Multivariate statistical methods are effective tools to reduce the raw data about pollutants' migration and for the analysis of multi-components in physical and chemical assessments [6]. Multivariate statistical approach, including cluster analysis (CA) and factor analysis (FA), is a frequently utilized tool for analyzing water quality by drawing logical inferences [7-11]. Multivariate analysis is frequently used to classify and assess groundwater and it is valuable for the detection of regional differences induced by natural and anthropogenic sources $[7,11,12]$.

The purpose of this analysis was to examine six physico-chemical parameters and important heavy metals in the groundwater samples from the Karak District, Pakistan. The broad data set collected was subjected to multivariate CA and FA techniques to evaluate information on similarities and dissimilarities between the various sampling sites; to classify water quality variables for spatial dissimilarity; and to determine the effect of the contamination factors on the water quality parameters.

\section{MATERIAL AND METHODS}

\subsection{Study area}

In the Karak District, Pakistan, the arid and semi-arid regions were the study zone of the research. Karak lies in the southern part of Khyber Pakhtunkhwa. The geological location of the study sites was $33^{\circ} 7^{\prime} 12^{\prime \prime} \mathrm{N}, 71^{\circ} 5^{\prime} 41^{\prime \prime} \mathrm{E}$. The area is rocky with deep valleys and interconnected spurs.
Karak is an arid region with an estimated yearly rainfall of around 320-330 millimeters, which can change periodically and have different intensities [13]. The present research was planned to determine the correlations between physical and chemical parameters and selected heavy metals in the groundwater of the Karak District.

\subsection{Sampling}

The groundwater samples were collected in the field by three different methods (hand pump, bore holes and tube wells) using the Global Positioning System (GPS) within the study area. Overall, 47 groundwater samples were collected from the study zone. Among these 47 samples, 12 samples were collected by hand pump, 21 by bore holes and 14 samples were collected from tube wells. The overall collected groundwater samples were collected into clean, sterilized and air-tight 2-liter polyethylene bottles. Aqua regia (concentrated nitric acid and concentrated hydrochloric acid in a molar ratio of 1:3) was used for the dissolving and fixing of all metals in the samples.

\subsection{Method of analysis}

Physical tests of groundwater, such as $\mathrm{pH}(781 \mathrm{pH}$ Meter, Metrohm AG, Herisau, Switzerland), electrical conductivity (EC Thermo Fisher, USA), total dissolved solids (TDS), temperature (Temp) and dissolved oxygen (DO) (with a DO Meter Thermo Fisher, USA) were performed in the field. Temperatures of the collected water samples were also checked with the help of thermometer. The selected heavy metals ( $\mathrm{HMs})$, including lead $(\mathrm{Pb}(\mathrm{II}))$, silver $(\mathrm{Ag}(\mathrm{I}))$, iron $(\mathrm{Fe}(\mathrm{II}))$ and chromium $(\mathrm{Cr}(\mathrm{VI}))$ were measured by the Atomic Absorption Spectrometer (Perkin Elmer, AAS-PEA-700, USA) under the measuring protocol of the Department of Chemistry, Abdul Wali Khan University Mardan, Khyber Pakhtunkhwa, Pakistan.

\subsection{Statistical analysis}

For mathematical and statistical analysis Microsoft Excel (ver. 2007) and IBM SPSS 26 were used in this study. During the collection of water samples, the GIS device (eTrex10, Garmin, Kansas City, USA) was employed and the study site maps were created on the ArcMap (ver. 10.5) (Fig. 1).

\section{RESULTS AND DISCUSSION}

\subsection{Groundwater parameters}

Different metals were analyzed in groundwater samples to assess the pollution level caused by heavy metals. The 


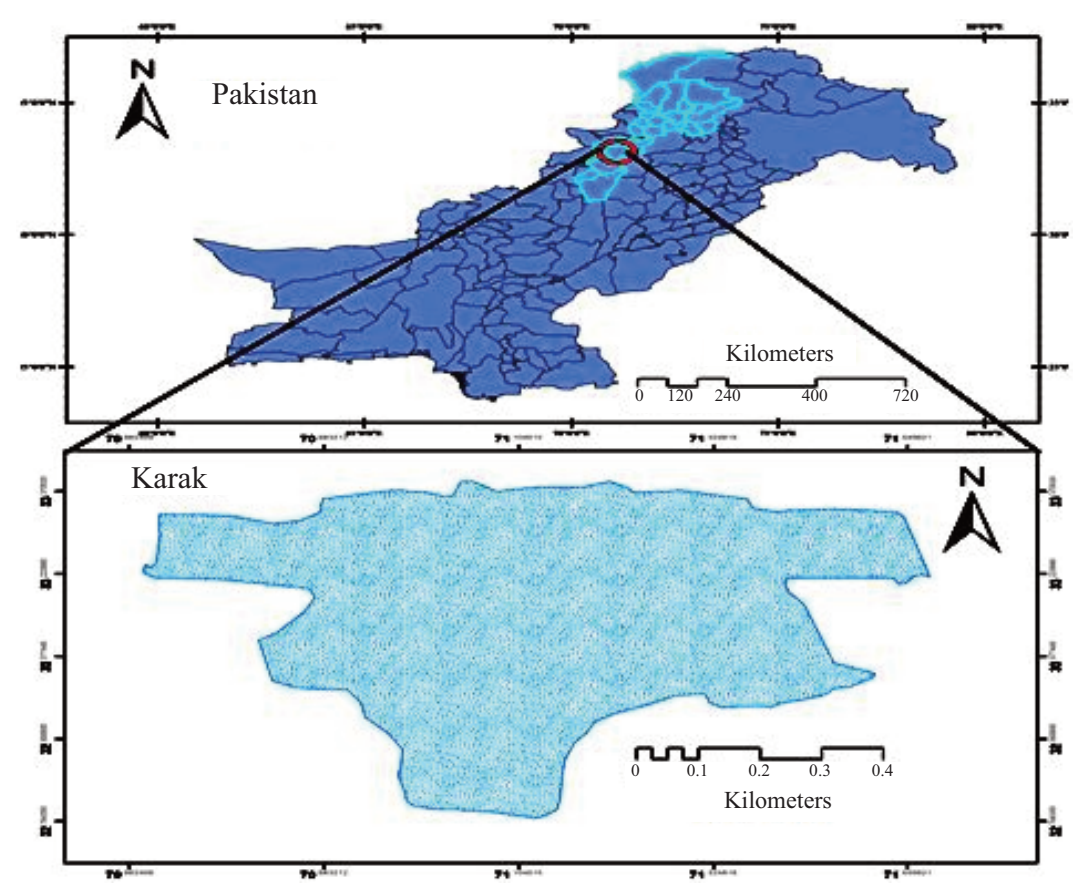

Fig. 1. Site of sampling in the Karak District, Pakistan.

analyzed metals included lead ( $\mathrm{Pb}(\mathrm{II}))$, silver $(\mathrm{Ag}(\mathrm{I}))$, iron (Fe(II)) and chromium (Cr(VI)) as some of the most toxic metals affecting human health.

The permissible limit of $\mathrm{Pb}(\mathrm{II})$ in groundwater suggested by the WHO and the Pakistan Council of Research in Water Resources (PCRWR) is $0.01 \mathrm{mg} / \mathrm{L}$ $[14,15]$. The concentration of $\mathrm{Pb}(\mathrm{II})$ in the $\mathrm{HP}$ water samples ranged from $0.65 \mathrm{mg} / \mathrm{L}$ to $2.65 \mathrm{mg} / \mathrm{L}$, in the $\mathrm{BH}$ water samples it was between $0.3 \mathrm{mg} / \mathrm{L}$ and $4.6 \mathrm{mg} / \mathrm{L}$ and in the TW water samples the concentration was in the range of $0.35 \mathrm{mg} / \mathrm{L}$ and $7 \mathrm{mg} / \mathrm{L}$, as shown in Table 1 .

The investigation showed that silver $(\operatorname{Ag}(\mathrm{I}))$ also constituted an important part in the collected water samples (Fig. 2). The permissible limit of $\mathrm{Ag}(\mathrm{I})$ in groundwater samples is $0.025 \mathrm{mg} / \mathrm{L}$. This limit has been suggested by the PCRWR and the WHO [14,15]. The concentration of $\operatorname{Ag}(\mathrm{I})$ in the water samples of the HP was detected from $0.105 \mathrm{mg} / \mathrm{L}$ to $0.113 \mathrm{mg} / \mathrm{L}$, in the $\mathrm{BH}$ groundwater samples it ranged from $0.103 \mathrm{mg} / \mathrm{L}$ to $0.114 \mathrm{mg} / \mathrm{L}$, while in the TW groundwater samples it was between $0.103 \mathrm{mg} / \mathrm{L}$ and $0.192 \mathrm{mg} / \mathrm{L}$, which exceeds the permissible limit for the research zone and may affect the local communities.

In general, Fe is a prevalent element in the Earth's crust, mainly in the form of ferro-magnesium silicates, as well as being a significant element in certain soils [16]. The limit of iron (Fe(II)) recommended by the WHO and the PCRWR in groundwater is $0.3 \mathrm{mg} / \mathrm{L}[15,17]$. The concentration of iron (Fe(II)) in the groundwater samples collected by the HP from the research zone ranged from $0.98 \mathrm{mg} / \mathrm{L}$ to $7.07 \mathrm{mg} / \mathrm{L}$, in the $\mathrm{BH}$ groundwater samples it was between $0.69 \mathrm{mg} / \mathrm{L}$ and $6.65 \mathrm{mg} / \mathrm{L}$ while the concentration of $\mathrm{Fe}(\mathrm{II})$ in the TW water samples was in the range of $0.51 \mathrm{mg} / \mathrm{L}$ and $5.22 \mathrm{mg} / \mathrm{L}$, as shown in Table 1 . The concentration of $\mathrm{Fe}(\mathrm{II})$ often exceeded the permissible limits suggested by the WHO and the PCRWR.

Chromium $(\mathrm{Cr})$ occurs in a trivalent form, which seems to be a balanced and non-hazardous type, and in another shape, i.e. hexavalent chromium - chromium that poses a threat to health. Trivalent chromium types are seldom present in drinking water [15]. The limit of $\mathrm{Cr}(\mathrm{VI})$ in groundwater suggested by the PCRWR and the WHO is $0.05 \mathrm{mg} / \mathrm{L}[14,15]$. In the study area the concentration of $\mathrm{Cr}(\mathrm{VI})$ in the HP water samples was detected in the range of $0.05 \mathrm{mg} / \mathrm{L}$ and $0.16 \mathrm{mg} / \mathrm{L}, \mathrm{Cr}(\mathrm{VI})$ in the $\mathrm{BH}$ water samples ranged from $0.04 \mathrm{mg} / \mathrm{L}$ to $0.13 \mathrm{mg} / \mathrm{L}$, while the concentration of $\mathrm{Cr}(\mathrm{VI})$ in the TW water samples was detected in the range of $0.03 \mathrm{mg} / \mathrm{L}$ and $0.2 \mathrm{mg} / \mathrm{L}$, as shown in Tables 1-4.

\subsection{Physico-chemical parameters in samples}

It was reported that the depth and water table of individual water sources were mainly different. For the sampling by hand pump (HP) the water table (WT) was 7.6-43 m while the overall water source depth (WSD) was detected between 24-76 m. The bore hole $(\mathrm{BH})$ sampling had a WT of 3.4-168 $\mathrm{m}$ and the WSD was 91-198 $\mathrm{m}$. The tube well (TW) WT was 18-168 $\mathrm{m}$ while the WSD ranged from 37 to $213 \mathrm{~m}$ as shown in Table 1 . The $\mathrm{pH}$ values showed the influence of the groundwater to respond to the alkaline 
Table 1. Water table (WT), water source depth (WSD), physico-chemical parameters (pH, electrical conductivity (EC)), dissolved oxygen (DO) saturation, total dissolved solids (TDS) and heavy metals in different sources of the groundwater. Standard deviation (Std Dev) and relative standard deviation (RSD) are also indicated

\begin{tabular}{|c|c|c|c|c|c|c|c|c|c|c|c|c|}
\hline \multirow{8}{*}{ 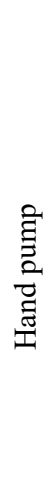 } & \multicolumn{12}{|c|}{ Groundwater samples' physico-chemical parameters } \\
\hline & Variable & $\begin{array}{l}\text { WT } \\
\text { (m) }\end{array}$ & $\begin{array}{l}\text { WSD } \\
(\mathrm{m})\end{array}$ & $\mathrm{pH}$ & $\begin{array}{c}\text { EC } \\
(\mu \mathrm{S} / \mathrm{cm})\end{array}$ & $\begin{array}{c}\text { DO sat. } \\
(\%)\end{array}$ & $\begin{array}{l}\text { Temp } \\
\left({ }^{\circ} \mathrm{C}\right)\end{array}$ & $\begin{array}{c}\text { TDS } \\
(\mathrm{mg} / \mathrm{L})\end{array}$ & $\begin{array}{l}\mathrm{Pb}(\mathrm{II}) \\
(\mathrm{mg} / \mathrm{L})\end{array}$ & $\begin{array}{l}\operatorname{Ag}(\mathrm{I}) \\
(\mathrm{mg} / \mathrm{L})\end{array}$ & $\begin{array}{l}\mathrm{Fe}(\mathrm{II}) \\
(\mathrm{mg} / \mathrm{L})\end{array}$ & $\begin{array}{l}\mathrm{Cr}(\mathrm{VI}) \\
(\mathrm{mg} / \mathrm{L})\end{array}$ \\
\hline & Min & 7.6 & 24 & 7.53 & 559.3 & 51.3 & 29.6 & 374.7 & 0.65 & 0.105 & 0.98 & 0.05 \\
\hline & Max & 43 & 76 & 8.31 & 7674 & 96.1 & 29.9 & 5141.6 & 2.65 & 0.113 & 7.07 & 0.16 \\
\hline & Median & 15.4 & 46 & 7.97 & 1808.5 & 82.95 & 29.85 & 1211.7 & 2.1 & 0.11 & 2.1 & 0.095 \\
\hline & Mean & 18 & 42 & 7.9 & 2103.3 & 78.6 & 29.8 & 1409.2 & 1.7 & 0.1 & 2.5 & 0.09 \\
\hline & Std Dev & & & & & & & & 0.8 & 0.002 & 1.6 & 0.029 \\
\hline & RSD & & & & & & & & 45.7 & 2.11 & 65 & 32.2 \\
\hline \multirow{6}{*}{$\begin{array}{l}\frac{0}{0} \\
\frac{0}{0} \\
\text { ஸे }\end{array}$} & Min & 3.4 & 91 & 7.34 & 449.4 & 54.1 & 29.5 & 301.1 & 0.3 & 0.103 & 0.69 & 0.04 \\
\hline & Max & 168 & 198 & 8.64 & 6324 & 109.9 & 29.9 & 4237.1 & 4.6 & 0.114 & 6.65 & 0.13 \\
\hline & Median & 37 & 76 & 7.73 & 1046 & 92.3 & 29.8 & 700.8 & 1.15 & 0.106 & 1.71 & 0.08 \\
\hline & Mean & 51 & 83 & 7.82 & 2329.7 & 90.3 & 29.8 & 1560.9 & 1.5 & 0.11 & 2.11 & 0.08 \\
\hline & Std Dev & & & & & & & & 0.99 & 0.003 & 1.27 & 0.03 \\
\hline & RSD & & & & & & & & 67.9 & 2.53 & 60.3 & 31.2 \\
\hline \multirow{6}{*}{$\begin{array}{l}\overline{0} \\
\vdots \\
0 \\
\equiv \\
\equiv\end{array}$} & Min & 18 & 37 & 7.6 & 351 & 91 & 29 & 235.2 & 0.35 & 0.103 & 0.51 & 0.03 \\
\hline & Max & 168 & 213 & 8.44 & 9784 & 113.5 & 29.9 & 6555.3 & 7 & 0.192 & 5.22 & 0.2 \\
\hline & Median & 116 & 175 & 8 & 871.5 & 100 & 29.8 & 584.0 & 1.85 & 0.109 & 1.485 & 0.105 \\
\hline & Mean & 106 & 156 & 7.91 & 1370.9 & 100.1 & 29.7 & 918.5 & 1.88 & 0.12 & 1.69 & 0.1 \\
\hline & Std Dev & & & & & & & & 1.66 & 0.02 & 1.14 & 0.05 \\
\hline & RSD & & & & & & & & 88.3 & 20.98 & 67.1 & 47.2 \\
\hline
\end{tabular}

content contained in the water. The collected groundwater samples had a different range of $\mathrm{pHs}$ maintained by different sources. The $\mathrm{pH}$ of the HP water samples was in the range of 7.53 and 8.31 , the $\mathrm{BH}$ water samples had the $\mathrm{pH}$ between 7.34 and 8.64 while the $\mathrm{pH}$ of the TW water samples ranged from 7.6 to 8.44 (Table 1, Fig. 3). The permissible limit of the $\mathrm{pH}$ in fresh water specified by the WHO is between 6.5 and 8.5 [14]. The electrical conductivity (EC) of the collected water samples ranged from $559.3 \mu \mathrm{S} / \mathrm{cm}$ to $7674 \mu \mathrm{S} / \mathrm{cm}$ for the HP, the EC of the $\mathrm{BH}$ was detected from $449.4 \mu \mathrm{S} / \mathrm{cm}$ to $6324 \mu \mathrm{S} / \mathrm{cm}$ while in the TW water samples the EC was in the range of $351 \mu \mathrm{S} / \mathrm{cm}$ and $9784 \mu \mathrm{S} / \mathrm{cm}$ (Table 1). The range of the TDS in the HP water samples reached from $374.7 \mathrm{mg} / \mathrm{L}$ to $5141.6 \mathrm{mg} / \mathrm{L}$. In the $\mathrm{BH}$ water samples the TDS ranged from $301.1 \mathrm{mg} / \mathrm{L}$ to $4237.1 \mathrm{mg} / \mathrm{L}$ while in the TW water samples the TDS was detected to be between $235.2 \mathrm{mg} / \mathrm{L}$ and $6555.3 \mathrm{mg} / \mathrm{L}$ (Table 1). Although high concentrations of the TDS can cause gastrointestinal effects in humans, they may also contribute to laxative effects. High TDS values can be linked to differences in geological compositions as well as to hydrological factors [18].

The dissolved oxygen (DO) parameter was also investigated in the water samples collected from the study area. In the HP water samples, the DO saturation values were detected in the range of $51.3 \%$ and $96.1 \%$, in the $\mathrm{BH}$ water samples they were between $54.1 \%$ and $109.9 \%$, while in the TW water samples the DO values were in the range of $91 \%$ and $113.5 \%$ [19]. Although the lack of DO in groundwater can be due to odoriferous anaerobic decomposition products [5], the concentration of DO (under $100 \%$ saturation) may also be affected by temperature as shown by Rajendran et. al. [20]. The temperature of the HP water samples was in the range of $29.6{ }^{\circ} \mathrm{C}$ and $29.9^{\circ} \mathrm{C}$, the temperature of the $\mathrm{BH}$ water samples was measured from $29.5^{\circ} \mathrm{C}$ to $29.9^{\circ} \mathrm{C}$, while the TW water samples' temperature was detected in the range of $29^{\circ} \mathrm{C}$ and $29.9^{\circ} \mathrm{C}$. 
(a)

$\mathrm{Pb}$ concentration in Karak groundwater

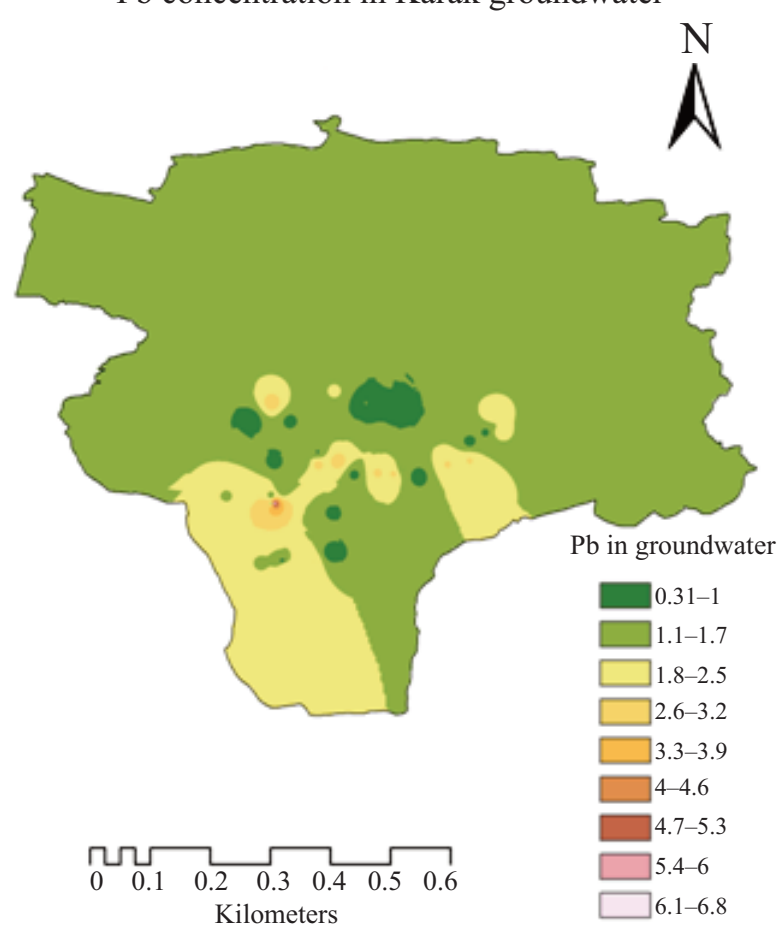

(c)

Fe concentration in Karak groundwater

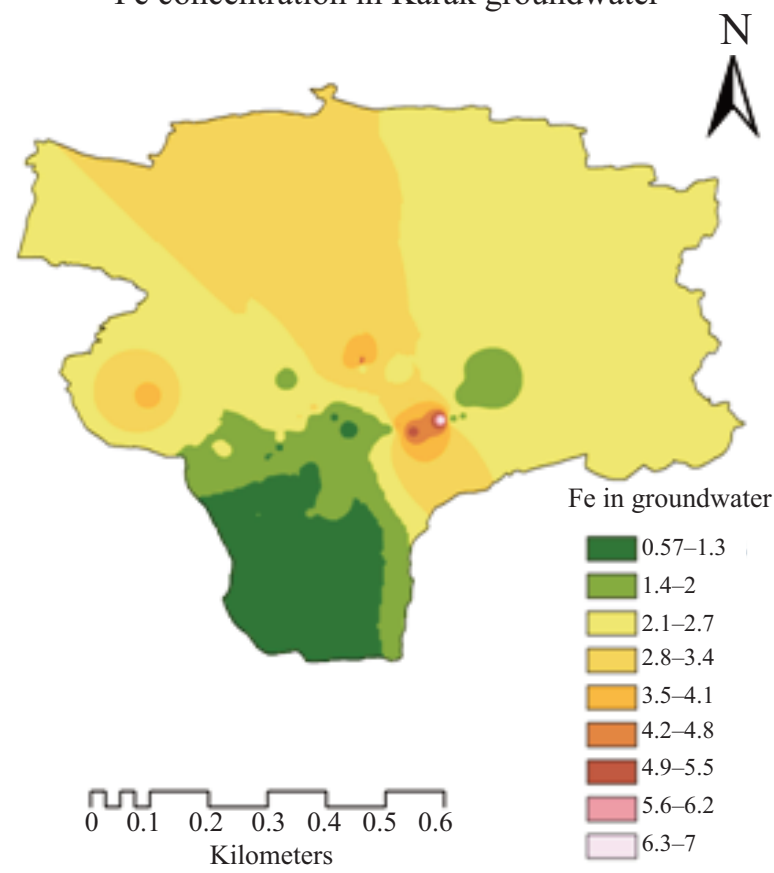

(b)

Ag concentration in Karak groundwater

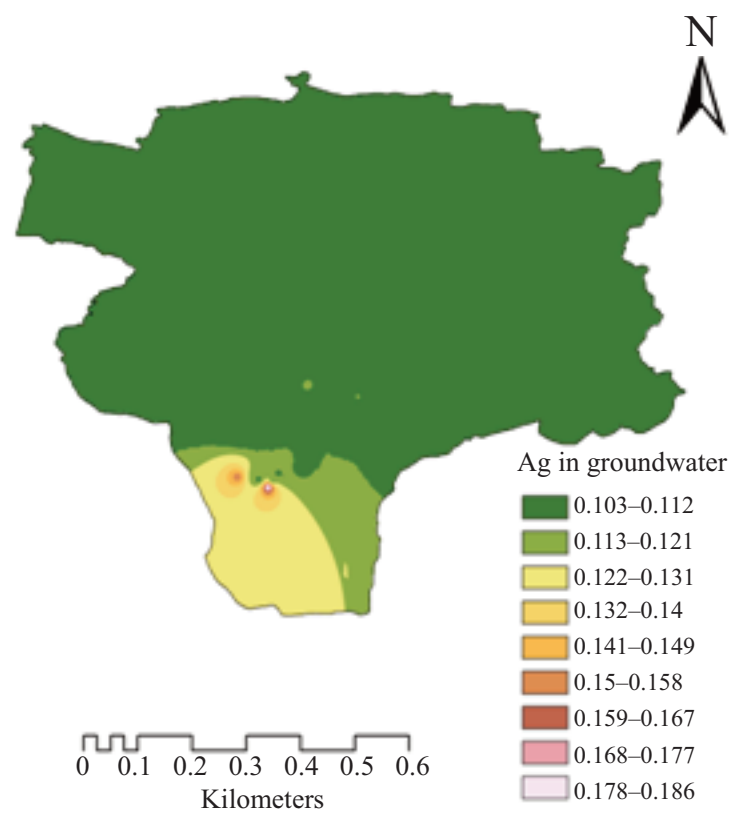

(d)

Cr concentration in Karak groundwater

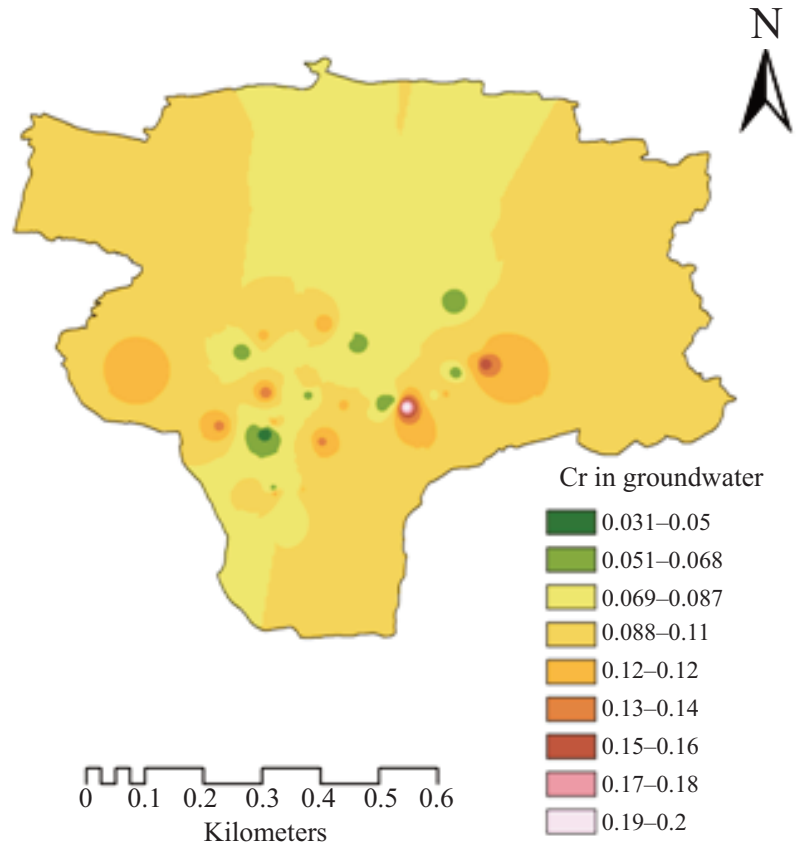

Fig. 2. Concentration of heavy metals (HMs) in $\mathrm{mg} / \mathrm{L}$ in different groundwater samples: (a) - Pb(II), (b) - Ag(I), (c) - Fe(II), (d) $-\mathrm{Cr}(\mathrm{VI})$ concentration. 


\subsection{Correlation coefficient $(r)$ analysis}

The Pearson correlation analysis (PCA) findings for the physico-chemical parameters and the HMs in the groundwater of the research region were observed. The PCA results for the physico-chemical parameters and the HM content of the study zone are summarized in Tables 2, 3 and 4. The inter-element relations present valuable details on the origins and routes of the HMs and the physico-chemical parameters. The intensity $r$, known as a linear correlation coefficient, shows the frequency and existence of the statistically significant correlations between the two parameters. The linear correlation coefficient is also referred to as the Pearson product- moment correlation coefficient. The formula for the calculation of " $r$ " is as follows:

$$
r=\frac{n \sum x y-\left(\sum x\right)\left(\sum y\right)}{\sqrt{n\left(\sum x^{2}\right)-\left(\sum x\right)^{2}} \sqrt{n\left(\sum y^{2}\right)-\left(\sum y\right)^{2}}},
$$

where $n$ is the number of pairs of data.

The correlation coefficient ranges from +1 to -1 . A correlation of +1 means a completely good relationship between the two parameters. When the significance of one variable increases, the significance of another parameter will increase at a parallel point. A correlation of -1 means when one variable varies inversely with another - as the

Table 2. Correlation matrix of HP water parameters in the study area, high correlations are shown in yellow

\begin{tabular}{|c|c|c|c|c|c|c|c|c|c|c|c|}
\hline & WT & WSD & $\mathrm{pH}$ & $\mathrm{EC}$ & DO & Temp & TDS & $\mathrm{Pb}$ & $\mathrm{Ag}$ & $\mathrm{Fe}$ & $\mathrm{Cr}$ \\
\hline WT & 1 & & & & & & & & & & \\
\hline WSD & 0.625 & 1 & & & & & & & & & \\
\hline $\mathrm{pH}$ & 0.096 & -0.243 & 1 & & & & & & & & \\
\hline $\mathrm{EC}$ & 0.067 & -0.061 & -0.266 & 1 & & & & & & & \\
\hline DO & -0.041 & -0.367 & -0.379 & 0.115 & 1 & & & & & & \\
\hline Temp & -0.632 & -0.446 & -0.189 & -0.349 & 0.493 & 1 & & & & & \\
\hline TDS & 0.067 & -0.061 & -0.266 & 1 & 0.115 & -0.349 & 1 & & & & \\
\hline $\mathrm{Pb}$ & 0.465 & 0.470 & -0.460 & -0.221 & 0.222 & -0.187 & -0.221 & 1 & & & \\
\hline $\mathrm{Ag}$ & 0.355 & 0.210 & -0.109 & 0.241 & -0.027 & -0.631 & 0.241 & 0.549 & 1 & & \\
\hline $\mathrm{Fe}$ & 0.042 & -0.189 & -0.067 & -0.007 & 0.515 & 0.269 & -0.007 & 0.129 & 0.105 & 1 & \\
\hline $\mathrm{Cr}$ & 0.573 & 0.864 & -0.128 & 0.278 & -0.372 & -0.548 & 0.278 & 0.144 & 0.146 & -0.207 & 1 \\
\hline
\end{tabular}

Table 3. Correlation matrix of $\mathrm{BH}$ water parameters in the study area, high correlations are shown in yellow

\begin{tabular}{|c|c|c|c|c|c|c|c|c|c|c|c|}
\hline & WT & WSD & $\mathrm{pH}$ & EC & DO & Temp & TDS & $\mathrm{Pb}$ & $\mathrm{Ag}$ & $\mathrm{Fe}$ & $\mathrm{Cr}$ \\
\hline WT & 1 & & & & & & & & & & \\
\hline WSD & 0.859 & 1 & & & & & & & & & \\
\hline $\mathrm{pH}$ & 0.212 & 0.149 & 1 & & & & & & & & \\
\hline EC & -0.240 & -0.413 & -0.193 & 1 & & & & & & & \\
\hline DO & 0.371 & 0.379 & 0.461 & 0.066 & 1 & & & & & & \\
\hline Temp & 0.103 & 0.133 & 0.024 & 0.059 & 0.102 & 1 & & & & & \\
\hline TDS & -0.240 & -0.413 & -0.193 & 1 & 0.066 & 0.059 & 1 & & & & \\
\hline $\mathrm{Pb}$ & -0.070 & -0.104 & -0.393 & -0.215 & -0.071 & 0.109 & -0.215 & 1 & & & \\
\hline $\mathrm{Ag}$ & 0.046 & 0.050 & -0.010 & -0.491 & 0.024 & -0.113 & -0.491 & 0.379 & 1 & & \\
\hline $\mathrm{Fe}$ & -0.252 & -0.054 & -0.142 & 0.373 & -0.038 & 0.047 & 0.373 & -0.311 & -0.501 & 1 & \\
\hline $\mathrm{Cr}$ & 0.179 & 0.243 & -0.180 & 0.167 & 0.070 & -0.233 & 0.167 & -0.235 & 0.050 & -0.128 & 1 \\
\hline
\end{tabular}


Table 4. Correlation matrix of TW water parameters in the study area, high correlations are shown in yellow

\begin{tabular}{l|c|c|c|c|c|c|c|c|c|c|c}
\hline & WT & WSD & pH & EC & DO & Temp & TDS & Pb & Ag & Fe & Cr \\
\hline WT & 1 & & & & & & & & & & \\
WSD & 0.815 & 1 & & & & & & & & \\
pH & 0.314 & -0.041 & 1 & & & & & & & \\
EC & -0.169 & -0.384 & 0.571 & 1 & & & & & & \\
DO & 0.631 & 0.437 & 0.048 & $-2 \mathrm{E}-05$ & 1 & & & & & \\
Temp & 0.159 & 0.324 & 0.415 & $1 \mathrm{E}-01$ & -0.168 & 1 & & & & \\
TDS & -0.169 & -0.384 & 0.571 & 1 & $-1.1 \mathrm{E}-05$ & 0.120 & 1 & & & \\
Pb & 0.170 & 0.212 & -0.324 & -0.209 & 0.449 & -0.093 & -0.209 & 1 & & \\
Ag & 0.442 & 0.340 & 0.262 & -0.125 & 0.042 & 0.056 & -0.125 & -0.013 & 1 & \\
Fe & -0.736 & -0.755 & 0.018 & 0.253 & -0.349 & 0.087 & 0.253 & -0.155 & -0.254 & 1 \\
Cr & -0.390 & -0.414 & 0.321 & 0.283 & -0.325 & 0.550 & 0.283 & -0.304 & -0.156 & 0.720 & 1
\end{tabular}
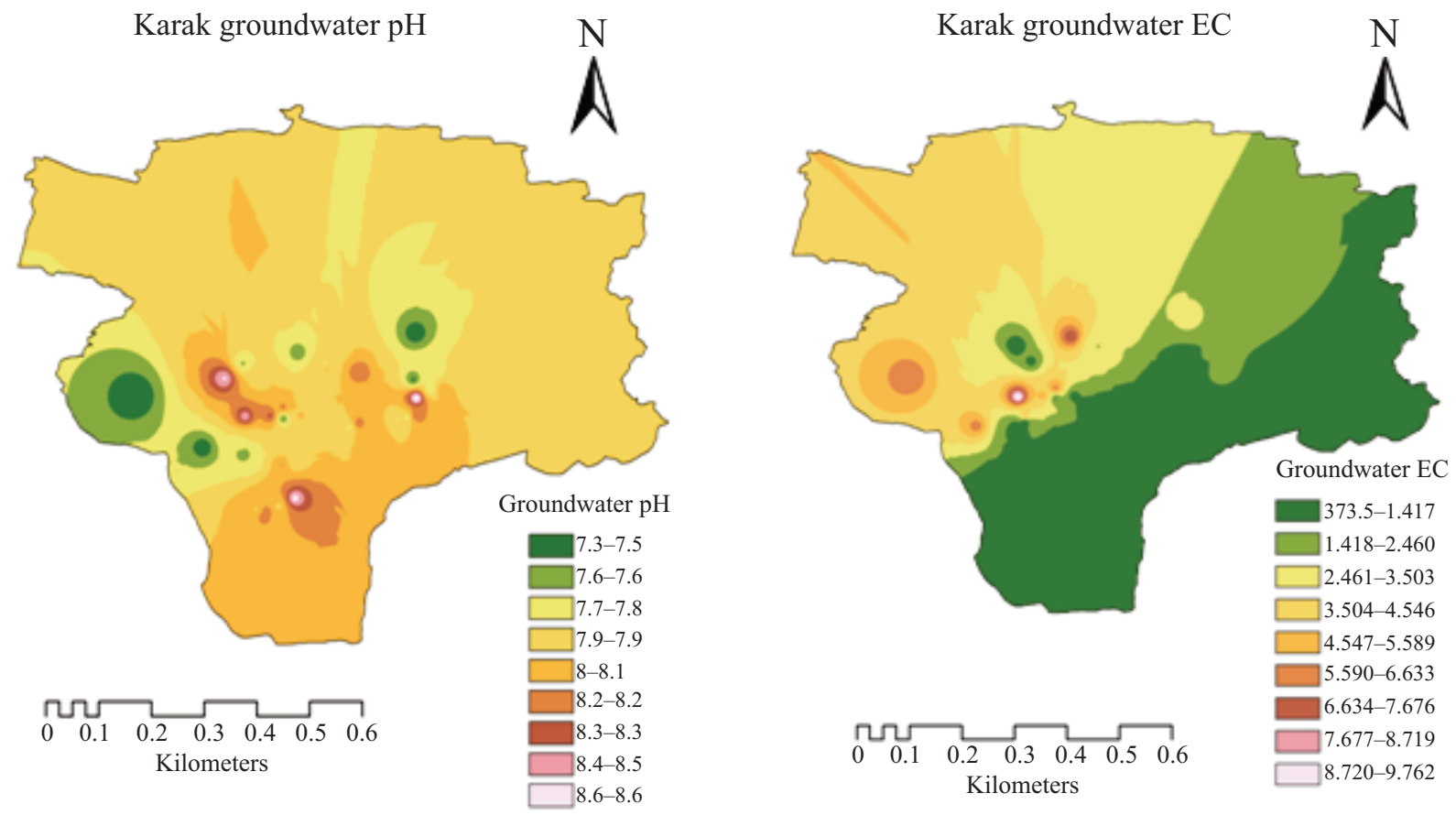

Fig. 3. The $\mathrm{pH}$ content and electrical conductivity (EC) of groundwater in $\mu \mathrm{S} / \mathrm{cm}$ in different locations.

importance of one variable increases - the significance of all other variables will decrease at the same time. In fact, there is a continuum of worse than ideal interactions here between two values, like zero, which often implies that there is no interface between the two variables [21]. The terms powerful, center and commonly assigned towards " $r$ " (correlation coefficient) value refer to a range $>1$, $1-0.864,0.864-0.859,0.859-0.815,0.815-0.720,0.720-$ $0.631,0.631-0.615$.
The correlation between the HP water sample parameters is shown in Table 2. The correlation between the WT and the WSD is $0.625(r)$, between the WSD and Cr it is $0.864(r)$ while a strong correlation lies between the TDS and the EC, which is $1(r)$. Table 3 shows the correlation between the parameters of the $\mathrm{BH}$ water samples. In Table 3, the relation between the WT and the WSD is $0.859(r)$ while a strong correlation lies between the TDS and the EC, which is $1(r)$. Table 4 displays the correlation 
between the parameters of the TW water samples. As demonstrated in Table 4, the relation between the WT and the WSD is $0.815(r)$, for DO and the WT it is $0.631(r)$, for $\mathrm{Cr}(\mathrm{VI})$ and $\mathrm{Fe}(\mathrm{II})$ it is $0.720(r)$. The strongest relation is shown between the TDS and the EC, the value of which is $1(r)$.

\subsection{Hierarchical cluster analysis (HCA)}

The Hierarchical Cluster Analysis (HCA) is a mixture of methods for classifying broad information into clusters at the level of similarity or dissimilarity. As a consequence, the resultant classes are identical to one another, yet different in certain categories. Investigators have also commonly used the HCA to identify water quality $[22,23]$. In the present study the HCA was applied to group samples and their similarities in water quality as well as to determine linkages across the water quality variables. The results of the HCA are given as dendrograms (Figs 4, 5 and 6). Figure 4 shows the dendrogram of the parameters of those water samples which were collected by the HP, Fig. 5 illustrates the BH dendrogram and Fig. 6 presents the dendrogram of the water samples which were collected from the TW in the research zone.

Among the HP water sample dendrograms there are two clusters. Cluster 1 contains seven parameters while Cluster 2 contains four parameters, as shown in Fig. 4. The $\mathrm{BH}$ dendrogram has two clusters. Cluster 1 contains three parameters while Cluster 2 has eight parameters, as shown in Fig. 5. Likewise, the TW dendrogram has two clusters. Cluster 1 contains six parameters while Cluster 2 has five parameters, as illustrated in Fig. 6.

The dendrograms using Ward Linkage are given in Figs 4, 5 and 6.

Different factors can be interconnected and have an effect on the groundwater and surface water quality.

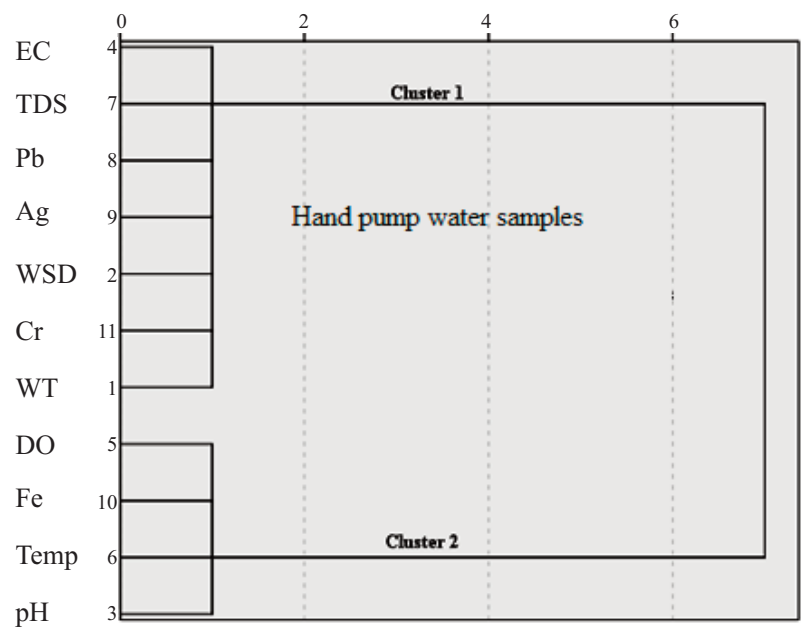

Fig. 4. HCA dendrogram (using Ward Linkage) of HP water parameters.

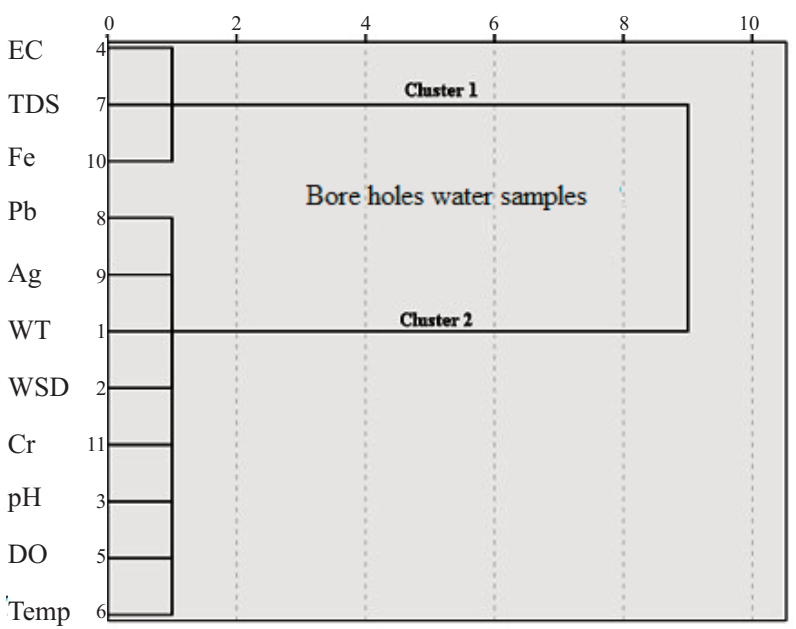

Fig. 5. HCA dendrogram (using Ward Linkage) of BH water parameters.

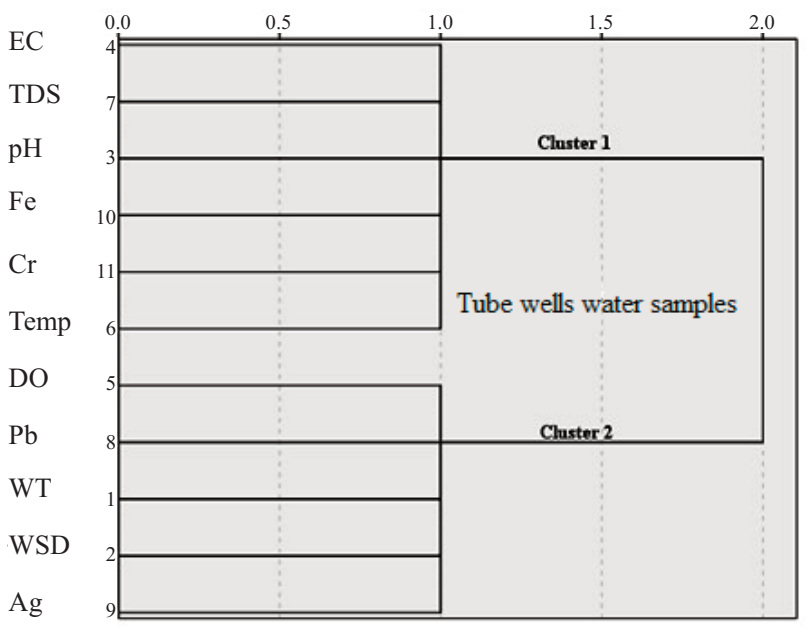

Fig. 6. HCA dendrogram of TW water parameters.

Studies have shown that landfill impacts the hydrological cycle and could cause groundwater pollution [24]. Likewise, phosphorus (P) has been considered a pollutant causing eutrophication in different water bodies when released into the environment untreated [25]. Earlier studies have also shown the effect of dissolved organic carbon (DOC), that it is dependent on the hydrological factors taking part in many biogeochemical reactions in Lake Võrtsjärv, Estonia [26].

\section{CONCLUSIONS}

In this study different multivariate statistical tools were applied for the evaluation of three different groundwater sources (samples collected by HP, BH and TW) in the arid and semiarid regions of the Karak District, Khyber 
Pakhtunkhwa, Pakistan. Different parameters ( $\mathrm{pH}, \mathrm{EC}$, WT, WSD, TDS, DO, Pb(II), Fe(II), Cr(VI) and Ag(I)) were studied for the collected groundwater samples. Some parameters of those samples were beyond their permissible limits, suggested by the WHO and the Pakistan Council of Research in Water Resources. The permissible limits of $\mathrm{Cr}(\mathrm{VI}), \mathrm{Ag}(\mathrm{I})$ and $\mathrm{Pb}(\mathrm{II})$ in groundwater are 0.05 , 0.025 and $0.01 \mathrm{mg} / \mathrm{L}$, respectively, but often the limits were exceeded in the studied samples. The concentration of $\mathrm{Cr}(\mathrm{VI})$ in the HP water samples was detected in the range of $0.05 \mathrm{mg} / \mathrm{L}$ and $0.16 \mathrm{mg} / \mathrm{L}, \mathrm{Cr}(\mathrm{VI})$ in the $\mathrm{BH}$ water samples was between $0.04 \mathrm{mg} / \mathrm{L}$ and $0.13 \mathrm{mg} / \mathrm{L}$. The concentration of $\mathrm{Ag}(\mathrm{I})$ in the HP water samples ranged from $0.105 \mathrm{mg} / \mathrm{L}$ to $0.113 \mathrm{mg} / \mathrm{L}$, in the $\mathrm{BH}$ groundwater samples it was from $0.103 \mathrm{mg} / \mathrm{L}$ to $0.114 \mathrm{mg} / \mathrm{L}$, while in the TW groundwater samples it was detected from $0.103 \mathrm{mg} / \mathrm{L}$ to $0.192 \mathrm{mg} / \mathrm{L}$. The concentration of $\mathrm{Pb}(\mathrm{II})$ in the HP water samples was between $0.65 \mathrm{mg} / \mathrm{L}$ and $2.65 \mathrm{mg} / \mathrm{L}$, in the $\mathrm{BH}$ water samples it ranged from $0.3 \mathrm{mg} / \mathrm{L}$ to $4.6 \mathrm{mg} / \mathrm{L}$ and in the TW water samples the concentration range was detected between $0.35 \mathrm{mg} / \mathrm{L}$ and $7 \mathrm{mg} / \mathrm{L}$. The minimum and maximum quantities of the physico-chemical parameters were in correlation between the matrices, showing strong relations between the parameters. Among all the parameters, the strongest relations were observed between the EC and the TDS.

\section{ACKNOWLEDGEMENTS}

The authors are thankful to Pak-US Project (No. 6-4/PAKUS/HEC/2015/04) PI for providing the laboratory and other facilities. This research was also funded by Project No. T190087MIMV and the European Commission through EU-India Project MLTKT19481R "Identifying best available technologies for decentralized wastewater treatment and resource recovery for India", EIC funded Project SLTKT20427 "Sewage sludge treatment from heavy metals, emerging pollutants and recovery of metals by fungi", as well as EIC Projects No. 15392 and No. 15401. The publication costs of this article were covered by the Estonian Academy of Sciences.

\section{REFERENCES}

1. Shekhar, S. and Pandey, A. C. Delineation of groundwater potential zone in hard rock terrain of India using remote sensing, geographical information system (GIS) and analytic hierarchy process (AHP) techniques. Geocarto Int., 2015, 30(4), 402-421. https://doi.org/10.1080/10106049.2014.894584

2. Lee, S., Kim,Y.-S. and Oh, H.-J. Application of a weightsof-evidence method and GIS to regional groundwater productivity potential mapping. J. Env. Manag., 2012, 96(1), 91-105. https://doi.org/10.1016/j.jenvman.2011.09.016
3. Tahmassebipoor, N., Rahmati, O., Noormohamadi, F. and Lee, S. Spatial analysis of groundwater potential using weights-of-evidence and evidential belief function models and remote sensing. Arab. J. Geosci., 2016, 9, 79. https://doi.org/10.1007/s12517-015-2166-Z

4. Ibrahim, A. K., Ahmed, S. H., Radeef, A. Y. and Hazzaa, M. M. Statistical analysis of groundwater quality parameters in selected sites at Kirkuk governorate/Iraq. IOP Conf. Ser.: Mater. Sci. Eng., 2021, 1058, 012028.

5. Simu, S., Uddin, M. J., Majumder, R. K., Zaman, M. N., Rahman, M. A. and Kashem, M. A. Speciation analysis of elements of soil samples by XRF in Gazipur industrial area, Bangladesh. Int. J. Mod. Res. Eng. Technol., 2018, 3(3), 12-23.

6. Belkhiri, L. and Mouni L. B. L. Multivariate statistical techniques for the evaluation of spatial variation in groundwater quality of Soummam basin (Algeria). Research Journal of Earth and Planetary Studies, 2011, 20, 7.

7. Helena, B., Pardo, R., Vega, M., Barrado, E., Fernandez, J. M. and Fernandez, L. Temporal evolution of groundwater composition in an alluvial aquifer (Pisuerga River, Spain) by principal component analysis. Water Res., 2000, 34(3), 807816. https://doi.org/10.1016/S0043-1354(99)00225-0

8. Brodnjak-Vončina, D., Dobčnik, D., Novič, M. and Zupan, J. Chemometrics characterisation of the quality of river water. Anal. Chim. Acta, 2002, 462(1), 87-100. https://doi.org/10.1016/S0003-2670(02)00298-2

9. Reghunath, R., Murthy, T. R. S. and Raghavan, B. R. The utility of multivariate statistical techniques in hydrogeochemical studies: an example from Karnataka, India. Water Res., 2002, 36(10), 2437-2442. https://doi.org/ 10.1016/S0043-1354(01)00490-0

10. Simeonov, V., Stratis, J. A., Samara, C., Zachariadis, G., Voutsa, D., Anthemidis, A., Sofoniou, M. and Kouimtzis, Th. Assessment of the surface water quality in Northern Greece. Water Res., 2003, 37(17), 4119-4124. https://doi.org/ 10.1016/S0043-1354(03)00398-1

11. Singh, K. P., Malik, A., Mohan, D. and Sinha, S. Multivariate statistical techniques for the evaluation of spatial and temporal variations in water quality of Gomti River (India) - a case study. Water Res., 2004, 38(18), 39803992. https://doi.org/10.1016/j.watres.2004.06.011

12. Belkhiri, L., Boudoukha, A., Mouni, L. and Baouz, T. Application of multivariate statistical methods and inverse geochemical modeling for characterization of groundwater -A case study: Ain Azel plain (Algeria). Geoderma, 2010, 159 (3-4), 390-398. https://doi.org/10.1016/j.geoderma.2010.08.016

13. Tabassum, I. Desertification dynamics and its control mechanisms in semiarid areas of Pakistan: A case study of District Karak. PhD thesis. Institute of Geography, Urban and Regional Planning, University of Peshawar, Pakistan, 2012.

14. Guidelines for Drinking-Water Quality. 4th edition. WHO, Geneva, 2011.

15. National Water Quality Monitoring Programme. Pakistan Council of Research in Water Resources (PCRWR), Islamabad, Pakistan, 2007.

16. Hooda, P. S. Trace Elements in Soils. John Wiley \& Sons, Hoboken, NJ, 2010.

17. Guidelines for Drinking-Water Quality. WHO, Geneva, 2017. 
18. Sharma, D. A., Rishi, M. S. and Keesari, T. Evaluation of groundwater quality and suitability for irrigation and drinking purposes in southwest Punjab, India using hydrochemical approach. Appl. Water Sci., 2017, 7, 31373150. https://doi.org/10.1007/s13201-016-0456-6

19. Oak, N., Mandalekar, P., Gurav, S., Gokhale, P., Pawar, A. and Kundiya, K. Design and develop water quality monitoring system. Int. Eng. J. Res. Dev., 2020, 5(5), 8. https://doi.org/10.17605/OSF.IO/EUQF7

20. Rajendran, A. and Mansiya, C. Physico-chemical analysis of ground water samples of coastal areas of south Chennai in the post-Tsunami scenario. Ecotoxicol. Environ. Saf., 2015, 121, 218-222. https://doi.org/10.1016/j.ecoenv.2015.03.037

21. Wang, S.-W., Liu, C.-W. and Jang, C.-S. Factors responsible for high arsenic concentrations in two groundwater catchments in Taiwan. Appl. Geochem., 2007, 22(2), 460476. https://doi.org/10.1016/j.apgeochem.2006.11.011

22. Gibrilla, A., Bam, E. K. P., Adomako, D., Ganyaglo, S., Osae, S., Akiti, T. T. et al. Application of Water Quality Index (WQI) and multivariate analysis for groundwater quality assessment of the Birimian and Cape Coast granitoid complex: Densu River Basin of Ghana. Water Qual. Expo. Health, 2011, 3(63). https://doi.org/10.1007/s12403-0110044-9

23. Tiri, A., Lahbari, N. and Boudoukha, A. Assessment of the quality of water by hierarchical cluster and variance analyses of the Koudiat Medouar Watershed, East Algeria. Appl. Water Sci., 2017, 7, 4197-4206. https://doi.org/10.1007/ s13201-014-0261-z

24. Pehme, K.-M., Burlakovs, J., Kriipsalu, M., Pilecka, J., Grinfelde, I., Tamm, T., Jani, Y. and Hogland, W. Urban hydrology research fundamentals for waste management practices. Rural Environ. Eng., 2019, 1, 160-167. https:// doi.org/10.22616/rrd.25.2019.024

25. Saaremäe, E., Liira, M., Poolakese, M. and Tamm, T. Removing phosphorus with $\mathrm{Ca}-\mathrm{Fe}$ oxide granules - a possible wetlands filter material. Hydrol. Res., 2014, 45(3), 368-378. https://doi.org/10.2166/nh.2013.101

26. Tamm, T., Nõges, T., Järvet, A. and Bouraoui, F. Contributions of DOC from surface and groundflow into Lake Võrtsjärv (Estonia). Hydrobiologia, 2008, 599, 213220. https://doi.org/10.1007/s10750-007-9189-8

\title{
Pakistani Karaki piirkonna põhjavee raskmetallide ja füüsikalis-keemiliste omaduste mitme muutujaga statistiline analüüs
}

\author{
Asif Khan, Muhammad Naeem, Ivar Zekker, Muhammad Balal Arian, Greg Michalski, \\ Syed Zeeshan, Hameed ul Haq, Muhammad Ikram, Abbas Khan, Fazle Subhan, Yahya Jani, \\ Zane Vincevica-Gaile, Muhammad Zahoor, Indrees Khan ja Muhammad Ishaq Ali Shah
}

Põhjavee raskmetallireostus on kogu maailmas suur probleem. Põhjaveeproovide analüüsimiseks võeti pinnase- ja veeproove raskmetallide ning füüsikalis-keemiliste omaduste hindamiseks Pakistanist Karaki piirkonna eri kohtadest. Globaalse infosüsteemi (GIS) abil koguti ja kaardistati 47 põhjavee ning pinnaseproovi asukohad. Uuringus keskenduti veetasemele (WT), veeallika sügavusele (WSD), pH-le, elektrijuhtivusele (EC), lahustunud hapnikule (DO), kogu suspendeeritud tahkele ainele (TDS), pliile $(\mathrm{Pb})$, hõbedale $(\mathrm{Ag})$, rauale $(\mathrm{Fe})$ ja kroomi $(\mathrm{Cr})$ parameetritele. Raskmetalle analüüsiti aatomabsorptsiooni spektrofotomeetriga (AAS). Pearsoni korrelatsioonimaatriks näitas seoseid mitme parameetri vahel, nagu elektrijuhtivus ja kogu suspendeeritud tahke aine, kuna need olid tihedas korrelatsioonis kõigi kolme erineva põhjaveekogumi vahel. TDSi ja EC vahel leiti tugev seos kõigist veeallikatest, mille regressioonikordaja ( $r$ ) oli 1. Tehti ka hierarhilist klasterdamist (dendrogrammide järgi), kus proovid sisaldasid kuni 2 klastrit, milles oli kuni 8 parameetrit. 